\title{
Molecular characterization of Clostridium perfringens isolated from cattle and sheep carcasses and its antibiotic resistance patterns in Shiraz slaughterhouse, southern Iran
}

\author{
Saeid Hosseinzadeh ${ }^{1 *}$, Maryam Bahadori², Maryam Poormontaseri', \\ Maryam Dehghani ${ }^{3}$, Mahdi Fazeli ${ }^{3}$, and Saeed Nazifi ${ }^{4}$ \\ ${ }^{1}$ Department of Food Hygiene and Public Health, School of Veterinary Medicine, \\ Shiraz University, Shiraz, Iran \\ ${ }^{2}$ Department of Pathobiology, School of Veterinary Medicine, Shiraz University, Shiraz, Iran \\ ${ }^{3}$ Department of Basic Sciences, School of Veterinary Medicine, Shiraz University, Shiraz, Iran \\ ${ }^{4}$ Department of Clinical Studies, School of Veterinary Medicine, Shiraz University, Shiraz, Iran
}

\begin{abstract}
HOSSEINZADEH, S., M. BAHADORI, M. POORMONTASERI, M. DEHGHANI, M. FAZELI, S. NAZIFI: Molecular characterization of Clostridium perfringens isolated from cattle and sheep carcasses and its antibiotic resistance patterns in Shiraz slaughterhouse, southern Iran. Vet. arhiv 88, 581-591, 2018.
\end{abstract}

\section{ABSTRACT}

Clostridium perfringens type A food-borne poisoning is often caused by C. perfringens enterotoxin (CPE) encoded by chromosomal cpe. Contamination of meat with $C$. perfringens usually leads to food poisoning outbreaks. To find more information regarding the causative agent, we focused on the identification of type A containing cpe and netB genes in cattle and sheep carcasses slaughtered at Shiraz slaughterhouse and investigated the prevalence of antibiotic-resistant plasmid in isolated C. perfringens. 200 specimens were randomly collected by swabbing the whole outer and inner surface of the carcasses, and processed for selective culture on sulfadiazine polymyxin sulphate agar (SPS). The suspected colonies were further identified using species-specific primers as to confirm the presence of the cpa, cpe, netB and tetracycline and enrofloxacin gene resistance patterns. Our results demonstrated that out of 90 and 70 colonies of the positive cultures from cattle and sheep samples, respectively, $40 \%$ and $35.7 \%$ of the suspected colonies were identified as C. perfringens type A by PCR assay. Moreover, from those type A isolates, only $1(2.7 \%)$ isolate was positive for both cpe and net $B$ genes in the cattle carcasses. The MIC values also showed high tetracycline resistance patterns for cattle (45.8\%) and sheep (92.3\%) while all of the PCR positive C. perfringens type $A$ isolates were susceptible to enrofloxacin. The high prevalence of $C$. perfringens in slaughtered animals with a high rate of resistance to tetracycline implies the need for caution in the use of antibiotic in food animals.

Key words: Clostridium perfringens; cpe and netB genomes; antibiotic resistance

\footnotetext{
*Corresponding author:
}

S. Hosseinzadeh, PhD, DVM, Department of Food Hygiene and Public Health, School of Veterinary Medicine, Shiraz University, Shiraz, Iran, P.O. Box: 71441-69155, Iran, Phone: +98 7136138 743; Fax: +98 713228 6950; E-mail: hosseinzadeh@shirazu.ac.ir 


\section{S. Hosseinzadeh et al.: Characterization of Clostridium perfringens from cattle and sheep carcasses}

\section{Introduction}

Clostridium perfringens is a gram-positive, spore-forming, anaerobic bacterium, and an important cause of food-borne gastrointestinal (GI) diseases in both humans and animals (SONGER 1996; WEN and McCLANE 2004). The bacteria persist in nature and can be found in soil, and the intestinal tracts of human, animals and insects. Owing to being a spore-forming bacterium, C. perfringens is very resistant to external agents, which in turn favors their distribution (LINDSTROM et al., 2011). Different kinds of $C$. perfringens toxins, including enterotoxin (CPE), have been identified by serological and molecular methods (EL-MOEZ et al., 2013). C. perfringens type A, carrying chromosomal cpe, is the major cause of food poisoning in the world; while the majority of non-food borne gastrointestinal diseases such as sporadic diarrhea and antibioticassociated diarrhea are identified as plasmid-borne cpe. The reservoirs and transmission routes of enterotoxigenic $C$. perfringens are not entirely clear. Raw meat and poultry are typically considered as the major vehicles for the transmission of this enteropathogen (LAHTI et al., 2008; LINDSTROM et al., 2011). Moreover, C. perfringens may cause necrotic enteritis as an economic serious disease in chickens, followed by a pore forming toxin (NetB). A high prevalence of the toxin gene net $\mathrm{B}$ has been reported in slaughtered animals (MARTIN and SMYTH 2009).

Considering the ubiquitous nature and high load of $C$. perfringens in the GI tract of humans and animals, and also its resistance to multiple antimicrobial agents, it may play a role in the transfer of resistant plasmids to other gut microflora. On the other hand, the similarity of the genotypic and phenotypic characteristics of foodborne bacteria to the resistant bacteria of the GI tract is regarded as a cause of conjugative transfer of the resistant mobile genetic elements to each other. Moreover, the high amount of foodborne pathogens in animal products and the irregular use of anti-bacterial agents may lead to an increase in the rate of antibiotic resistance worldwide (TEUBER, 1999). However, previous publications have shown an increasing pattern of resistance, especially in meat products in developing countries (VAN et al., 2007). In cases of enterotoxigenic C. perfringens type A food poisoning, although antibiotic therapy is not of significant value, the presence of high frequencies of antibiotic resistant isolates may adversely affect the gut microflora (TEUBER, 1999). In the current study, we tried to determine the genotypic and phenotypic prevalence of $C$. perfringens carrying cpe and net $\mathrm{B}$ genes, and also identify multi-drug resistance patterns in the slaughtered animals.

\section{Materials and methods}

Sample collection and culture. From October 2012 to June 2013, 200 swab samples were randomly collected in thioglycolate broth from cattle $(n=100)$ and sheep $(n=100)$ carcasses at a Shiraz slaughterhouse, in the south of Iran. Sampling was carried out by 


\section{S. Hosseinzadeh et al.: Characterization of Clostridium perfringens ¡from cattle and sheep carcasses}

swabbing the whole outer and inner surfaces of the carcasses (SMART et al., 1979). The samples were immediately transferred to the laboratory on ice and sub-cultured anaerobically on selective culture media, sulfite polymyxin sulfadiazine (SPS) agar, followed by incubation at $37^{\circ} \mathrm{C}$ for $24 \mathrm{~h}$. Black colonies were considered as suspicious positive and were then identified by Gram's stain. The suspected colonies were chosen for DNA extraction and PCR assay using species-specific primers targeting the cpa, cpe, and netB genes in order to perform toxin typing (WU et al., 2009).

Animal ethics. The experiment was performed under the approval of the state committee on animal ethics, Shiraz University, Shiraz, Iran (IACUC no: 4687/63). The European Council Directive (86/609/EC) of November 24, 1986, ethic approval was employed in all the experiments.

DNA extraction. This was performed using the phenol-chloroform technique (SAMBROOK and RUSSELL 2006). The samples were centrifuged at $10000 \mathrm{~g}$; the supernatants were discarded; and $250 \mu \mathrm{L}$ buffer 1 (resuspension solution contained 100 $\mu \mathrm{g} / \mathrm{mL}$ RNase), $250 \mu \mathrm{L}$ buffer 2 (Lysis buffer), and $550 \mu \mathrm{L}$ saturated phenol were then added, followed by mixing and centrifuging at $8000 \mathrm{~g}$. The supernatant of each sample was collected into a new micro tube; the same volume of phenol was then added and centrifuged at the same speed. The clear phase was collected into a new tube, before adding sodium acetate ( $2 \mathrm{M}, \mathrm{pH} 5.2,0.1 \mathrm{X}$ volume of each aliquot). The aliquot was mixed with $1.5 \mathrm{~mL}$ of $100 \%$ ethanol, kept at $-20^{\circ} \mathrm{C}$ for 1 hour, and centrifuged at $12000 \mathrm{~g}$. The supernatant was then discarded and the DNA pellet was washed with counterpart $80 \%$ ethanol, before being dried and suspended in $30 \mu \mathrm{L}$ distilled water for further use.

Table 1. Primers used in the present study

\begin{tabular}{|c|c|c|c|c|}
\hline $\begin{array}{l}\text { Primer } \\
\text { name }\end{array}$ & Nucleotides (5'-3') & $\begin{array}{l}\text { Annealing } \\
\text { temperature } \\
\left({ }^{\circ} \mathrm{C}\right)\end{array}$ & $\begin{array}{l}\text { Amplicon } \\
\text { size (bp) }\end{array}$ & References \\
\hline $\begin{array}{l}\text { cpa } \mathrm{F} \\
\text { cpa } \mathrm{R}\end{array}$ & $\begin{array}{c}\text { GCTAATGTTACTGCCGTTGACC } \\
\text { TCTGATACATCGTGTAAG }\end{array}$ & 55 & 324 & WU et al., 2009 \\
\hline $\begin{array}{l}\text { cpe } \mathrm{F} \\
\text { cpe } \mathrm{R}\end{array}$ & $\begin{array}{l}\text { GGAGATGGTTGGATATTAGG } \\
\text { GGACCAGCAGTTGTAGATA }\end{array}$ & 55 & 233 & MIKI et al., 2008 \\
\hline 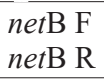 & $\begin{array}{l}\text { GCTGGTGCTGGAATAAATGC } \\
\text { TCGCCATTGAGTAGTTTCCC }\end{array}$ & 55 & 383 & TOLOOE et al., 2011 \\
\hline $\begin{array}{l}\operatorname{tet} \mathrm{A} \mathrm{F} \\
\text { tetA R }\end{array}$ & $\begin{array}{l}\text { GAAGGCAAGCAGGATGTAG } \\
\text { GAAGGCAAGCAGGATGTAG }\end{array}$ & 50 & 888 & $\begin{array}{l}\text { SCHWAIGER et al., } \\
2010\end{array}$ \\
\hline $\begin{array}{l}\text { gyrA F } \\
\text { gyrA R }\end{array}$ & $\begin{array}{l}\text { ATGAGCGAATTAGCCAAAGA } \\
\text { GCAACCGTCCAACACTTCAT }\end{array}$ & 52 & 582 & WANG et al., 2010 \\
\hline
\end{tabular}

PCR assay. Amplification of cpa gene. The presence of $C$. perfringens type A was confirmed by determination of the cpa gene (Table 1). Details of the primers and PCR cycle 
are given as follows: the PCR mixture was prepared in total volume of $25 \mu \mathrm{L}$ containing $\operatorname{MgCl} 2(2 \mathrm{mM}), 10 x$ PCR buffer $(2.5 \mu \mathrm{L})$, dNTPs $(200 \mathrm{mM})$, forward and reverse primer $(500 \mu \mathrm{M})$, and Taq DNA polymerase (2 units) (CinnaGen, Iran). PCR amplification was carried out as reported formerly (WU et al., 2009). After electrophoresing the amplified products in $1.5 \%$ agarose gel (Cinna Gen, Iran) and staining them with ethidium bromide, and a UV light was used for photographing.

Amplification of cpe gene. The detection of $C$. perfringens containing a cpe amplicon was based on the amplification of the gene using oligonucleotide primers (Table 1). The PCR mixture was prepared in a total volume of $25 \mu \mathrm{L}$ containing $\mathrm{MgCl} 2(2 \mathrm{mM}), 10 \mathrm{x}$ PCR buffer $(2.5 \mu \mathrm{L})$, dNTPs $(200 \mathrm{mM})$, forward and reverse primers $(400 \mu \mathrm{M})$, and Taq DNA polymerase (2 units) (CinnaGen, Iran). PCR cycling was carried out as publicized before (MIKI et al., 2008). After electrophoresing the amplified products in 1.5\% agarose gel (Cinna Gen, Iran) and staining them with ethidium bromide, a UV light was used for photographing.

Amplification of netB gene. A pair of primers was used to detect the fragment (Table 1). The PCR mixture was prepared in a total volume of $25 \mu \mathrm{L}$ containing $\mathrm{MgCl} 2(2.5$ $\mathrm{mM}), 10 \mathrm{x}$ PCR buffer $(2 \mu \mathrm{L})$, dNTPs $(0.2 \mathrm{mM})$, forward and reverse primers $(0.1 \mu \mathrm{M})$, and Taq DNA polymerase (2.5 units) (CinnaGen, Iran). Negative and positive controls were included in all PCR reactions. PCR cycling was carried out as publicized before (TOLOOE et al., 2011). After electrophoresing the amplified products in $1.5 \%$ agarose gel (Cinna Gen, Iran) and staining them with ethidium bromide, a UV light was used for photographing.

Amplification of tetracycline and enrofloxacin resistance genes. PCR assay was carried out to detect tetracycline (tetA) and enrofloxacin $(g y r \mathrm{~A})$ resistance genes using specific pairs of primers (Table 1). The PCR mixtures for both tet A and gyrA genes were prepared in a total volume of $25 \mu \mathrm{L}$, containing MgCl2 $(1.5 \mathrm{mM}), 10 \mathrm{x}$ PCR buffer $(2.5 \mu \mathrm{L})$, dNTPs mixture ( $0.5 \mathrm{mM}$ for tet $\mathrm{A}$ and $0.2 \mathrm{mM}$ for gyr $\mathrm{A}$ genes), forward and reverse primers $(0.3$ $\mu \mathrm{M}$ for tet $\mathrm{A}$ and $0.1 \mathrm{mM}$ for gyrA genes), and Taq DNA polymerase (2 units) (Cinna Gen, Iran). PCR cycling was carried out as explained in earlier publications (PAYOT et al., 2002; SCHWAIGER et al., 2010; WANG et al., 2010). After electrophoresing the amplified products in 1.5\% agarose gel (Cinna Gen, Iran) and staining them with ethidium bromide, a UV light was used for photographing.

Tetracycline and enrofloxacin susceptibility test. The antimicrobial susceptibility test was carried out using the MIC (Minimal Inhibitory Concentration) value, which was determined using the broth microdilution technique according to the Clinical and Laboratory Standards Institute (CLSI) guidelines (CLSI 2012). $100 \mu \mathrm{L}$ of double TSB was initially added to each well of 96-well panels. $100 \mu \mathrm{L}$ of each antibiotic of tetracycline $(400 \mu \mathrm{g} / \mathrm{mL})$ and enrofloxacin $(100 \mu \mathrm{g} / \mathrm{mL})$ was subsequently serially diluted 
in the wells, and $10 \mu \mathrm{L}$ of $C$. perfringens suspension $(105 \mathrm{CFU} / \mathrm{mL})$ was finally added to each well followed by incubation anaerobically at $37{ }^{\circ} \mathrm{C}$ for $24 \mathrm{~h}$ (the experiment was repeated in triplicate). The bacterial growth was determined by measuring the O.D. at $600 \mathrm{~nm}$ of each well (Bio Tek, USA). A C. perfringens strain was determined as a positive control, while TSB medium and antibiotics were considered as negative controls. The MIC was confirmed at the lowest dilution of an antibiotic component with visually complete inhibition of bacterial growth. The growth inhibition percentage of bacteria was reported using the equation as follows:

[(OD positive control (between $0 \mathrm{~h}$ to $24 \mathrm{~h}$ ) - OD samples (between $0 \mathrm{~h}$ to $24 \mathrm{~h}$ ))

/ OD positive control (between $0 \mathrm{~h}$ to $24 \mathrm{~h}$ )] $\times 100$ (KATHER et al., 2006).

Statistical analysis. To assess the statistically significant differences in the distribution of few anti-microbial resistance genes, a Chi-square contingency test was employed. A $\mathrm{P}$-value $<0.05$ was considered significant.

\section{Results}

PCR assays of cpa, cpe and netB genes. Out of 200 swab samples, 90 and 70 suspected colonies were respectively isolated from cattle and sheep on the SPS agar. The suspected colonies were then subjected to the PCR, and of these $36(40 \%)$ and $25(35.7 \%)$ were identified as $C$. perfringens type A (cpa-positive) in cattle and sheep, respectively. In addition, from the type A isolates, 1 (2.7\%) isolate was shown to carry both CPE and NetB in cattle, while no positive gene carriers were found in sheep (Table 2). $233 \mathrm{bp}$ and 383 bp amplicons corresponded to cpe and netB genes respectively (Fig. 1).

Table 2. Percentage of $c p a$, cpe and netB genes and tetracycline and enrofloxacin (tetA, gyrA) resistance genes from $C$. perfringens type $\mathrm{A}$

\begin{tabular}{|l|c|c|c|c|c|c|}
\hline Carcass & $\begin{array}{c}\text { Number of } \\
\text { presumptive } \\
\text { colonies }\end{array}$ & $\begin{array}{c}c p a \text {-positive } \\
\text { (type A) }\end{array}$ & type A-cpe & type A-netB & $\begin{array}{c}\text { type A-tetA } \\
\text { resistance }\end{array}$ & $\begin{array}{c}\text { type A- gyrA } \\
\text { resistance }\end{array}$ \\
\hline Cattle & 90 & $36(40 \%)$ & $1(2.7 \%)$ & $1(2.7 \%)$ & $24(66.7 \%)$ & $2(5.55 \%)$ \\
\hline Sheep & 70 & $25(35.7 \%)$ & 0 & 0 & $13(52 \%)$ & $1(4 \%)$ \\
\hline
\end{tabular}

Amplification of tetracycline and enrofloxacin resistance genes. The results revealed that $66.7 \%(24 / 36)$ and $52 \%(13 / 25)$ of the $C$. perfringens type A carried the tetA gene in cattle and sheep respectively. Moreover, $2(5.55 \%)$ and $1(4 \%)$ of the cattle and sheep isolates respectively, were resistant to the gyrA gene (Table 2). 888 bp and $582 \mathrm{bp}$ amplicons respectively corresponded to the tetA and gyrA genes (Fig. 2). 
S. Hosseinzadeh et al.: Characterization of Clostridium perfringens from cattle and sheep carcasses

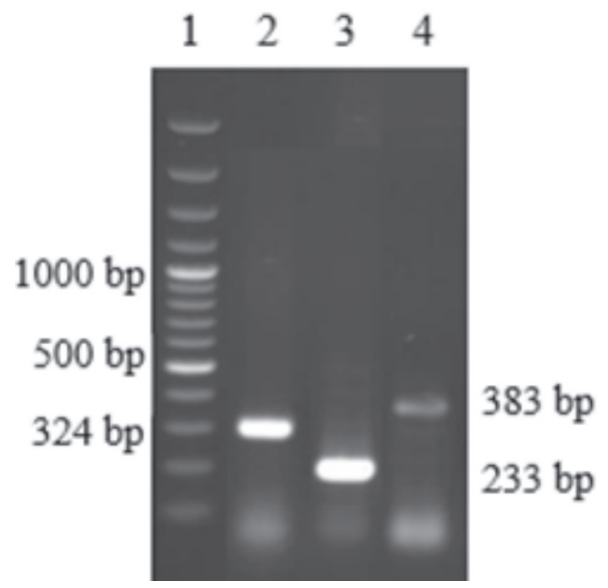

Fig 1. Representation of agarose gel electrophoresis for recognition of cpa, cpe and net $\mathrm{B}$ amplicons of $C$. perfringens using PCR reaction. Lane 1: 100 bp Marker, Lane 2, 3 and 4: 324 bp, $233 \mathrm{bp}$, and $383 \mathrm{bp}$ positive samples, respectively.

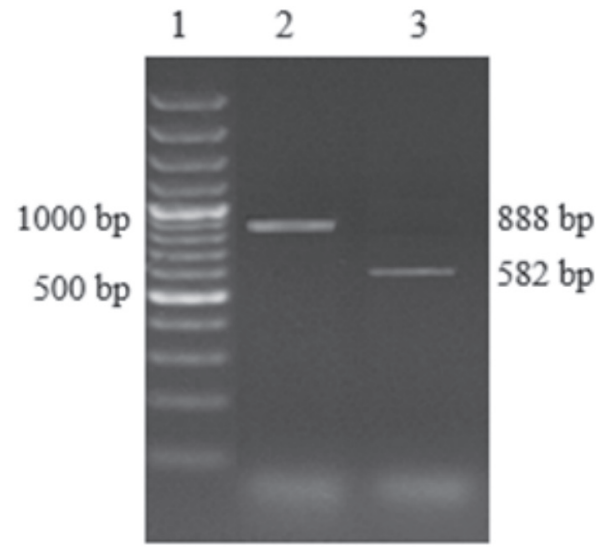

Fig 2. Representation of agarose gel electrophoresis for detection of tetA and gyrA resistance amplicons of $C$. perfringens using PCR reaction. Lane 1: 100 bp Marker, Lane 2 and 3: 888 bp and 582 bp positive samples respectively.

Tetracycline and enrofloxacin susceptibility test. The MIC values of tetracycline selected from cpa-positive $C$. perfringens isolates from cattle and sheep were determined in a concentration range of $3.12-25 \mu \mathrm{g} / \mathrm{mL}$. Of the tetA-positive isolates, $45.8 \%(11 / 24)$ and $92.3 \%$ (12/13) cattle and sheep respectively were shown to have high-level resistance $(\mathrm{MIC} \geq 16 \mu \mathrm{g} / \mathrm{mL})$. Moderate resistant levels $(4<\mathrm{MIC}<16 \mu \mathrm{g} / \mathrm{mL})$ were also found in 
$41.6 \%(10 / 24)$ and $7.7 \%(1 / 13)$ cattle and sheep, respectively. Furthermore, there was a significant relationship between high or moderate tetracycline resistance and tetA positive isolates in comparison of the susceptible isolates $(\mathrm{P}<0.05)$.

The MIC value for enrofloxacin recorded in the concentration range of 0.0002 $0.031 \mu \mathrm{g} / \mathrm{mL}$ for both animal species, indicated that all the $g y r$ A positive isolates were susceptible to enrofloxacin (MIC $\leq 4 \mu \mathrm{g} / \mathrm{mL}$ ) (Table 3).

Table 3. MIC values of tetracycline and enrofloxacin (tet $A$, gyrA ) resistance genes of $C$. perfringens in resistant and susceptible isolates from cattle and sheep

\begin{tabular}{|l|c|c|c|c|c|c|c|c|}
\hline & \multicolumn{2}{|c|}{ tetA (cattle) } & \multicolumn{2}{c|}{ tetA (sheep) } & \multicolumn{2}{c|}{ gyrA (cattle) } & \multicolumn{2}{c|}{ gyrA (sheep) } \\
\cline { 2 - 9 } & Positive & Negative & Positive & Negative & Positive & Negative & Positive & Negative \\
\hline $\begin{array}{l}\text { High-level } \\
\text { resistance MIC } \\
\geq 16 \mu \mathrm{g} / \mathrm{mL}\end{array}$ & 11 & 0 & 12 & 0 & 0 & 0 & 0 & 0 \\
\hline $\begin{array}{l}\text { Moderate-level } \\
\text { resistance } \\
\begin{array}{l}4<\mathrm{MIC} \\
<16 \mu \mathrm{g} / \mathrm{mL}\end{array}\end{array}$ & 10 & 0 & 1 & 2 & 0 & 0 & 0 & 0 \\
\hline $\begin{array}{l}\text { Susceptible } \\
\text { MIC } \\
\leq 4 \mu \mathrm{g} / \mathrm{mL}\end{array}$ & 3 & 12 & 0 & 10 & 0 & 36 & 0 & 25 \\
\hline Total & 24 & 12 & 13 & 12 & 0 & 36 & 0 & 25 \\
\hline
\end{tabular}

\section{Discussion}

CPE and NetB toxins are known to be the most important excretions produced by C. perfringens causing serious diseases in human and animals. Although C. perfringens is extensively distributed in the environment, just less than $5 \%$ of the pathogen strains carry the cpe gene (DAMME-JONGSTEN et al., 1989; KOKAI-KUN et al., 1994). About 40 outbreaks of $C$. perfringens foodborne GI diseases were recorded during 2000 to 2005 in Japan, and approximately 4000 people are estimated to become infected annually (MIKI et al., 2008). We found that the cattle and sheep carcasses slaughtered in Shiraz, Iran, were contaminated with C. perfringens type A at the rate of $40 \%$ and $35.7 \%$, respectively. Several studies have been conducted to determine the prevalence rate of cpe and $n e t \mathrm{~B}$ genes isolated from various sources, especially raw meat and poultry (WEN and McCLANE 2004). For instance, the occurrence of the net $\mathrm{B}$ gene isolated from chickens and cattle was reported as $9.2 \%$ and $1.4 \%$, respectively (MARTIN and SMYTH 2009). In American retail markets, C. perfringens was identified in $21 \%$ and $38 \%$ of beef and lamb respectively, and one was cpe-positive (WEN and McCLANE 2004). The incidence of 
C. perfringens isolates from slaughtered beef and lamb was found to be $29 \%$ and $85 \%$, respectively (SMART et al., 1979). In Japan, the results demonstrated that $45.7 \%$ and $33.3 \%$ of Japanese retail raw beef samples tested were contaminated with C. perfringens bacteria, and approximately $2 \%$ were cpe-positive (MIKI et al., 2008). A study carried out on the presence of $C$. perfringens in minced meat from the north-east of Iran showed that $12.5 \%$ of samples were contaminated with this pathogen, of which $18 \%$ carried cpa gene toxins. In addition, the rate of $C$. perfringens type A was $29.03 \%$ in broiler meat (AFSHARI et al., 2015a; AFSHARI et al., 2015b). Based on the previous studies, the variations in the prevalence of $C$. perfringens were probably associated with factors including the method of slaughter, the overall sanitation condition, the total number of samples, and the methods chosen to detect the bacteria.

Nowadays, antibiotic resistance is rising significantly in the developing world where antimicrobial drugs are utilized without restrictions, and as such this issue has attracted a great deal of concern (JEAN and HSUEH 2011). C. perfringens, as a microflora of the human and animal GI tracts, plays a crucial role in antibiotic resistance. Isolates taken from patients with antibiotic-associated diarrhea and sporadic diarrhea were considered as plasmid-borne cpe (MIKI et al., 2008; TANSUPHASIRI et al., 2005). Various reports have been published about the resistance to multiple antibiotics of $C$. perfringens strains in humans and animals (KATHER et al., 2006). According to this study, $66.7 \%$ and $52 \%$ of the C. perfringens type A isolates were tetracycline-resistant, and $5.55 \%$ and $4 \%$ were enrofloxacin-resistant, in cattle and sheep carcasses, respectively. The MIC values also showed high level tetracycline resistance for both cattle and sheep. Antimicrobial resistance to $C$. perfringens, isolated from various sources in Thailand, revealed that the highest resistance was attributed to tetracycline (56.2\%) using the agar dilution method (TANSUPHASIRI et al., 2005). Earlier studies reported that tetracycline resistance is the most common antimicrobial resistance (CHOPRA and ROBERTS 2001). KATHER et al. (2006) documented that $96 \%$ of the $C$. perfringens isolates were identified as tetA gene positive, while $22.5 \%$ of $C$. perfringens isolates were resistant to tetracycline, using the MIC technique. These results support our findings.

Even though the reservoirs of $C$. perfringens food poisoning are partially recognized, as this bacterium is naturally present in feces and it is actually the causative agent of human food poisoning and diarrhea, it seems that contamination is likely due to the poor handling of the carcasses, specifically at the time of slaughtering. We suggest that special attention should be paid to the evisceration process, and the spread of the feces onto the whole carcass throughout this task should also be avoided. 
S. Hosseinzadeh et al.: Characterization of Clostridium perfringens ¡from cattle and sheep carcasses

\section{Acknowledgements}

The authors would like to thank the Research Council of Shiraz University and School of Veterinary Medicine, Shiraz University for its financial and technical support of this study (Grant No.71-GR-VT-5).

\section{Conflicts of interest}

The authors declare that they have no conflicts of interest.

\section{Ethical approval}

All applicable international, national, and/or institutional guidelines for the care and use of animals were followed.

\section{References}

AFSHARI, A., A. JAMSHIDI, J. RAZMYAR (2015a): Molecular typing of Clostridium perfringens isolated from minced meat. IJVST. 7, 32-39.

DOI: 10.1111/j.1472-765X.2008.02379.x

AFSHARI, A., A. JAMSHIDI, J. RAZMYAR, M. RAD (2015b): Genotyping of Clostridium perfringens isolated from broiler meat in northeastern of Iran. Vet. Res. Forum 6, 279-284.

CHOPRA, I., M. ROBERTS (2001): Tetracycline antibiotics: mode of action, applications, molecular biology, and epidemiology of bacterial resistance. Microbiol. Mol. Biol. Rev. 65, 232-260.

DOI: 10.1128/MMBR.65.2.232-260.2001

CLSI (2012): Methods for antimicrobial susceptibility testing of anaerobic bacteria; Approved standard. $8^{\text {th }}$ ed. document M11-A8.

DAMME-JONGSTEN, M., K. WERNARS, S. NOTERMANS (1989): Cloning and sequencing of the Clostridium perfringens enterotoxin gene. Antonie Leeuwenhoek 56, 181-190.

DOI: $10.1007 / \mathrm{BF} 00399981$

EL-MOEZ, S. I. A., N. S. ATA, M. S. ZAKI (2013): Bacterial causes of sudden death in farm animals. Life Sci. J. 10, 1188-1201.

JEAN, S. S., P. R. HSUEH (2011): High burden of antimicrobial resistance in Asia. Int. J. Antimicrob. Agents 37, 291-295.

DOI: 10.1016/j.ijantimicag.2011.01.009

KATHER, E. J., S. L. MARKS, J. E. FOLEY (2006): Determination of the prevalence of antimicrobial resistance genes in canine Clostridium perfringens isolates. Vet. Microbiol. 113, 97-101.

DOI: $10.1016 /$ j.vetmic.2005.10.021

KOKAI-KUN, J. F., J. G. SONGER, J. R. CZECZULIN, F. CHEN, B. A. McCLANE (1994): Comparison of Western immunoblots and gene detection assays for identification of potentially enterotoxigenic isolates of Clostridium perfringens. J. Clin. Microbiol. 32, 2533-2539.

Vet. arhiv 88 (5), 581-591, 2018 
S. Hosseinzadeh et al.: Characterization of Clostridium perfringens from cattle and sheep carcasses

LAHTI, P., A. HEIKINHEIMO, T. JOHANSSON, H. KORKEALA(2008): Clostridium perfringens type A strains carrying a plasmid-borne enterotoxin gene (genotype IS1151-cpe or IS1470like-cpe) as a common cause of food poisoning. J. Clin. Microbiol. 46, 371-373.

LINDSTROM, M., A. HEIKINHEIMO, P. LAHTI, H. KORKEALA (2011): Novel insights into the epidemiology of Clostridium perfringens type A food poisoning. Food Microbiol. 28, 192-198.

MARTIN, T. G., J. A. SMYTH (2009): Prevalence of netB among some clinical isolates of Clostridium perfringens from animals in the United States. Vet. Microbiol. 136, 202-205.

DOI: 10.1016/j.vetmic.2008.10.026

MIKI, Y., K. MIYAMOTO, I. KANEKO-HIRANO, K. FUJIUCHI, S. AKIMOTO (2008): Prevalence and characterization of enterotoxin gene-carrying Clostridium perfringens isolates from retail meat products in Japan. Appl. Environ. Microbiol. 74, 5366-5372.

DOI: 10.1128/AEM.00783-08

PAYOT, S., A. CLOECKAERT, E. CHASLUS-DANCLA (2002): Selection and characterization of fluoroquinolone-resistant mutants of Campylobacter jejuni using enrofloxacin. Microb. Drug Resist. 8, 335-343.

DOI: $10.1089 / 10766290260469606$

SAMBROOK, J., D. W. RUSSELL (2006): Purification of nucleic acids by extraction with phenol: chloroform. Cold Spring Harbor Protocols 2006, pdb. prot4455.

SCHWAIGER, K., C. HÖLZEL, J. BAUER (2010): Resistance gene patterns of tetracycline resistant Escherichia coli of human and porcine origin. Vet. Microbiol. 142, 329-336.

DOI: 10.1016/j.vetmic.2009.09.066

SMART, J., T. ROBERTS, M. STRINGER, N. SHAH (1979): The incidence and serotypes of Clostridium perfringens on beef, pork and lamb carcasses. J. Appl. Bacteriol. 46, 377-383.

DOI: 10.1111/j.1365-2672.1979.tb00834.x

SONGER, J. G. (1996): Clostridial enteric diseases of domestic animals. Clin. Microbiol. Rev. 9, 216-234.

TANSUPHASIRI, U., W. MATRA, L. SANGSUK (2005): Antimicrobial resistance among Clostridium perfringens isolated from various sources in Thailand. Southeast Asian J. Trop. Med. Public Health 36, 954-961.

TEUBER, M. (1999): Spread of antibiotic resistance with food-borne pathogens. Cell. Mol. Life Sci. 56, 755-763.

DOI: $10.1007 / \mathrm{s} 000180050022$

TOlOOE, A., B. SHOJADOOST, S. PEIGHAMBARI, Y. TAMADDON (2011): Prevalence of netB gene among Clostridium perfringens isolates obtained from healthy and diseased chickens. J. Anim. Vet. Adv. 10, 106-110.

DOI: $10.3923 /$ javaa.2011.106.110

VAN, T. T. H., G. MOUTAFIS, L. T. TRAN, P. J. COLOE (2007): Antibiotic resistance in foodborne bacterial contaminants in Vietnam. Appl. Environ. Microbiol. 73, 7906-7911.

DOI: 10.1128/AEM.00973-07 
S. Hosseinzadeh et al.: Characterization of Clostridium perfringens $\gg$ from cattle and sheep carcasses

WANG, Y. C., J. P. W. CHAN, K. S. YEH, C. C. CHANG, S. L. HSUAN, Y. M. HSIEH, Y. C. CHANG, T. C. LAI, W. H. LIN, T. H. CHEN (2010): Molecular characterization of enrofloxacin resistant Actinobacillus pleuropneumoniae isolates. Vet. Microbiol. 142, 309-312.

DOI: 10.1016/j.vetmic.2009.09.067

WEN, Q., B. A. McCLANE (2004): Detection of enterotoxigenic Clostridium perfringens type A isolates in American retail foods. Appl. Environ. Microbiol. 70, 2685-2691.

DOI: 10.1128/AEM.70.5.2685-2691.2004

WU, J., W. ZHANG, B. XIE, M. WU, X. TONG, J. KALPOE, D. ZHANG (2009): Detection and toxin typing of Clostridium perfringens in formalin-fixed, paraffin-embedded tissue samples by PCR. J. Clin. Microbiol. 47, 807-810.

DOI: $10.1128 /$ JCM.01324-08

Received: 18 June 2017

Accepted: 2 June 2018

\section{HOSSEINZADEH, S., M. BAHADORI, M. POORMONTASERI, M. DEHGHANI, M. FAZELI, S. NAZIFI: Molekularna karakterizacija i otpornost na antibiotike bakterije Clostridium perfringens izolirane iz trupova goveda i ovaca u klaonicama Shiraza u južnom Iranu. Vet. arhiv 88, 581-591, 2018.}

\section{SAŽETAK}

Trovanje hranom uzrokovano bakterijom Clostridium perfringens tipa A često uzrokuje C. perfringens enterotoksin (CPE), kodiran kromosomskim cpe. Kontaminacija mesa s C. perfringens obično uzrokuje otrovanje hranom. Da bismo doznali više informacija o uzročniku, iz trupova goveda i ovaca zaklanih u klaonicama Shiraza, identificirali smo tip A koji sadržava gene cpe i netB. Osim toga, u izoliranim bakterijama $C$. perfringens utvrdili smo prevalenciju plazmida rezistentnih na antibiotike. Obriskom cijele vanjske i unutarnje površine nasumično odabranih trupova, prikupljeno je 200 uzoraka koji su obrađeni selektivnom kulturom na sulfadiazin-polimiksin sulfatnom agaru (SPS). Sumnjive kolonije dodatno su identificirane primjenom specifičnih početnica kako bi se potvrdila prisutnost gena cpa, cpe, netB te gena za otpornost na tetraciklin i enrofloksacin. Naši su rezultati pokazali da je PCR analizom od 90, odnosno 70 kolonija pozitivnih kultura iz uzoraka goveda i ovaca, njih $40 \%$, odnosno $35,7 \%$ identificirano kao $C$. perfringens tipa A. Štoviše, iz izolata tipa A dobivenih od goveđih trupova, samo je jedan izolat $(2,7 \%)$ bio pozitivan i za gene cpe i za netB. MIC vrijednosti također su pokazale visoku razinu otpornosti na tetracikline kod goveda $(45,8 \%)$ i ovaca $(92,3 \%)$, dok su svi PCR pozitivni na $C$. perfringens tipa A bili osjetljivi na enrofloksacin. Visoka prevalencija bakterije C. perfringens kod zaklanih životinja zajedno s visokom stopom otpornosti na tetraciklin upućuje na potrebu za oprezom u primjeni antibiotika kod životinja koje služe za ljudsku hranu.

Ključne riječi: Clostridium perfringens; genomi cpe i netB; otpornost na antibiotike 
